\title{
Magnesium-Gold Alloy Formation by Underpotential Deposition of Magnesium onto Gold from Nitrate Melts
}

\author{
Vesna S. Cvetković ${ }^{1, *}$, Niko Jovićević ${ }^{2}$, Jasmina S. Stevanović ${ }^{1}$, Miomir G. Pavlović ${ }^{1}$, \\ Nataša M. Vukićević ${ }^{1}$, Zoran Stevanović ${ }^{3}$ and Jovan N. Jovićević ${ }^{1}$ \\ 1 Institute of Chemistry, Technology and Metallurgy, Department of Electrochemistry, University of Belgrade, \\ Njegoševa 12, 110000 Belgrade, Serbia; jaca@tmf.bg.ac.rs (J.S.S.); duki@tmf.bg.ac.rs (M.G.P.); \\ vukicevic@ihtm.bg.ac.rs (N.M.V.); matori47@hotmail.com (J.N.J.) \\ 2 Nissan Technical Center North America, Inc., 39001 Sunrise Drive, Farmington Hills, MI 48331-3487, USA; \\ niko.jovicevic@nissan-usa.com \\ 3 Mining and Metallurgy Institute Bor, Zeleni bulevar 35, 19210 Bor, Serbia; jaca@tmf.bg.ac.rs \\ * Correspondence: v.cvetkovic@ihtm.bg.ac.rs; Tel.: +381-11-3640-228
}

Academic Editor: Hugo F. Lopez

Received: 22 November 2016; Accepted: 10 March 2017; Published: 15 March 2017

\begin{abstract}
Magnesium underpotential deposition on gold electrodes from magnesium nitrate-ammonium nitrate melts has been investigated. Linear sweep voltammetry and potential step were used as electrochemical techniques. Scanning electron microscopy (SEM), energy dispersive spectrometry (EDS) and X-ray diffraction (XRD) were used for characterization of obtained electrode surfaces. It was observed that reduction processes of nitrate, nitrite and traces of water (when present), in the $\mathrm{Mg}$ underpotential range studied, proceeded simultaneously with magnesium underpotential deposition. There was no clear evidence of $\mathrm{Mg} / \mathrm{Au}$ alloy formation induced by Mg UPD from the melt made from eutectic mixture $\left[\mathrm{Mg}\left(\mathrm{NO}_{3}\right)_{2} \cdot 6 \mathrm{H}_{2} \mathrm{O}+\mathrm{NH}_{4} \mathrm{NO}_{3} \cdot \mathrm{XH}_{2} \mathrm{O}\right]$. However, EDS and XRD analysis showed magnesium present in the gold substrate and four different $\mathrm{Mg} / \mathrm{Au}$ alloys being formed as a result of magnesium underpotential deposition and interdiffusion between $\mathrm{Mg}$ deposit and $\mathrm{Au}$ substrate from the melt made of a nonaqueous $\left[\mathrm{Mg}\left(\mathrm{NO}_{3}\right)_{2}+\mathrm{NH}_{4} \mathrm{NO}_{3}\right]$ eutectic mixture at $460 \mathrm{~K}$.
\end{abstract}

Keywords: magnesium/gold alloys; underpotential deposition; magnesium nitrate melts

\section{Introduction}

For some time now, gold $(\mathrm{Au})$ has roused interest in the field of solid state chemistry, materials science, optics, and organic light emitting diodes. In the semiconductor industry, owing to its high thermal and electrical conductivities, good oxidation resistance, and good workability, gold is a popular material for wiring. However, in the effort to improve the bonding and strength of thinner wires, cost reduction is one of the many challenges [1,2].

There are also gold-based catalysts, which, due to large-sized gold clusters made of closely packed gold atoms, represent a bridge between atomic state and bulk material. These have been developed [3,4] and increasingly used in many industries [5-7]. These gold-based metal catalyst are very active at low temperatures and are almost certainly more active than any other equivalent noble metal catalyst [5].

There has been an increase in research to develop gold-based alloys resistant to air, water, organic solvents, which would stand in as an alternative to pure gold and be well suited for particular technological applications $[1,2,7,8]$. A stable $\mathrm{Au} / \mathrm{Mg}$ alloy has a work function lower than gold and it is remarkably resistant to the effects of water and air, which makes it well suited for application in contact 
metallization in devices based on metal/semiconductor interfaces [1,4]. At the same time, $\mathrm{Mg} / \mathrm{Au}$ alloy is less cost-prohibitive than gold, improves bonding, and provides high electrical conductivity, better workability as a thinner wire and improved strength [1]. All these characteristics make the $\mathrm{Mg} / \mathrm{Au}$ alloy an attractive material for wiring for semiconductors. Gold-based catalysts doped with $\mathrm{Mg}$ atoms which hardly deform the electronic structure of $\mathrm{Au} / \mathrm{Mg}$ clusters demonstrate fascinating catalytic activity [3,9-11]. However, how the different structure of intermetallic $\mathrm{Au} / \mathrm{Mg}$ molecule affects the catalytic efficiency of the clusters is still an unresolved question which requires further study [3]. Being resistant to oxygen, water and organic solvents, and having relatively low work function, the $\mathrm{Au} / \mathrm{Mg}$ alloy has been successfully used as a cathode material in organic light emitting diodes (OLED) [2]. OLEDs are a key new technology for next generation full-color displays and energy saving solid state lightning. Degradation during exposure to oxygen and humidity is a serious issue which $\mathrm{Mg} / \mathrm{Au}$ alloy can overcome. $\mathrm{Au} / \mathrm{Mg}$ alloys have pronounced affinity for hydrogen and magnesium itself is considered to be a promising hydrogen storage material [12]. To avoid the drawbacks of the kinetics, efforts have been directed to preparing $\mathrm{Mg}$ nano-composites $[13,14]$ and $\mathrm{Mg}$ thin film is an efficient starting point for development. It is easy to investigate the size and microstructure effect on the hydrogen absorption and desorption kinetics due to the fact that the thickness, composition, interface and crystallinity are easily controllable [15]. There have been a number of reports on field-effect transistors using organic materials (OFETs) [2,16]. It was recognized that the injection of electrons from the $\mathrm{Au} / \mathrm{Mg}$ alloy layer as a source and drain electrodes is better than gold. The work function of $\mathrm{Au}$ layers is around $4.5 \mathrm{eV}$ and the work function of $\mathrm{Mg} / \mathrm{Au}$ layers is $3.7 \mathrm{eV}$, therefore $\mathrm{Mg} / \mathrm{Au}$ layers present a smaller barrier to the injection of holes from this electrode into a p-type organic layer with the highest occupied molecular orbital level of 5.0 to $5.5 \mathrm{eV}$ [2]. Lately there is an increased interest in magnesium as a battery anode, because the magnesium metal offers important advantages over both intercalation compounds and lithium metal, including a higher theoretical volumetric energy as well as a better availability due to abundance in the earth's crust [8,17-20]. Magnesium electrolytes remain in a relatively early developmental stage $[17,21,22]$. Despite the recent growth in efforts to develop efficient magnesium electrolytes, many challenges remain $[17,19]$. In any new electrolyte, magnesium deposition and dissolution from the working electrode has to be studied and Au electrode was assumed to be an ideal noble metal that does not participate in the reaction. Initially, it was assumed that there is no magnesium deposited upon the surface of the gold working electrode at potentials positive to its deposition potential from the used electrolyte [17].

Deposition of magnesium and formation of $\mathrm{Mg} / \mathrm{Au}$ alloy thin layers involves complicated procedures like: vacuum deposition, spattering, melt-spinning, high temperatures, controlled working atmosphere without humidity, etc. One of the most elegant ways to obtain alloys is an electrochemical deposition of a metal, or metals, onto another metal [23,24].

It was found that $\mathrm{Au} / \mathrm{Mg}$ alloys can be obtained by $\mathrm{Mg}$ electrodeposition onto gold from Grignard solution and these studies indicated that the alloys could be used as negative electrodes in rechargeable magnesium battery systems $[8,20]$.

However, magnesium onto gold substrate cannot be obtained by electrodeposition from aqueous solutions because hydrogen evolution on the working cathode starts at potentials more positive than magnesium deposition. This prevents even the smallest amounts of magnesium from remaining as a deposit on the cathode in an aqueous solution without being dissolved. In addition, $\mathrm{Mg}$ cannot be deposited from solutions of simple $\mathrm{Mg}$ salts, such as $\mathrm{Mg}\left(\mathrm{ClO}_{4}\right)_{4}$, in conventional organic solvents [8]. Most likely because the working electrode surface is covered by passivating surface films whose ionic conductivity is very low $[8,25]$.

Electrodeposition of $\mathrm{Mg}$ and its alloys is done from melts. For electrodeposition of $\mathrm{Mg}$, or other metals with very negative standard electrode potentials (Al, etc.), melts based on chloride salts at temperatures above $900 \mathrm{~K}$ are usually used [23]. Some of these melts include inorganic or organic chloride and fluoride salts combined with an organic or alkaline/alkaline earth metal cation or 
anion [24,26-28]. In addition, new ionic liquids proved to be suitable media for electrodeposition of metals and alloys at relatively low temperatures (from 273 to $373 \mathrm{~K}$ ) [29-31].

Possible usage of melts made with nitrates of alkaline and alkaline earth metals as electrolytes [32-34] became a subject of interest a few decades ago [32-36]. Among a number of nitrate melts investigated electrochemically, neither magnesium nitrate, nor magnesium nitrate/ammonium nitrate mixture melts were studied. To our knowledge, electrodeposition of magnesium, magnesium underpotential deposition and alloy formation from nitrate melts onto gold has not been reported.

Nitrate melts are electrochemically complicated media. Oxidative characteristics of nitrates at elevated temperatures are well known. Detailed investigations of the processes at potentials both positive or negative to the reversible potential of magnesium led to the recognition that a great number of oxidation/reduction processes with cations and anions present in nitrate melts can take place [33,34]. Any of them can hamper or even prevent the process of magnesium electrodeposition from nitrate melts. Difficulties in maintaining the intended melt temperature variation below $\pm 3 \mathrm{~K}$ arise from the large latent heats of the numerous nitrates phase transformations in the temperature range from $373 \mathrm{~K}$ to $500 \mathrm{~K}$ [35]. It should be noted that the presence of traces of water in magnesium melts cancels out the advantages of the melts as compared to the magnesium aqueous solutions. A key factor that contributes to this issue is that the backbone of magnesium nitrate hexahydrate octahedral complex is the magnesium cation $\left[\mathrm{Mg}\left(\mathrm{H}_{2} \mathrm{O}\right)_{6}\right]^{2+}$, which is very stable and does not release water thermally before it transforms into $\mathrm{MgO}$.

It is known that metals electrodeposited by underpotential deposition (electrodeposition of a metal onto foreign substrate at potentials more positive than the equilibrium potential of the depositing metal-UPD) onto a cathode of a different metal, generally, can diffuse into the substrate and generate alloys [23,37-41]. Alloys obtained by electrochemical deposition (overpotential deposition-OPD and UPD) can have different chemical and phase structures than the alloys of the same chemical composition obtained by metallurgical (thermal) methods [23,25,26,37-41].

The goal of this study, was to establish whether there is underpotential deposition of magnesium onto gold substrate from magnesium nitrate/ammonium nitrate melts, particularly one made from nonaqueous $\left[\mathrm{Mg}\left(\mathrm{NO}_{3}\right)_{2}+\mathrm{NH}_{4} \mathrm{NO}_{3}\right]$ eutectic mixture and is there possibility of $\mathrm{Mg} / \mathrm{Au}$ formation as a result of the process. This should help us to develop an easier way to form thermally stable surface magnesium/gold alloys.

\section{Materials and Methods}

The electrodeposition process was carried out in a three-electrode electrochemical cell made of Pyrex glass placed in a heating mantle designed for work with melts under a purified argon atmosphere $(99.99 \% \mathrm{Ar}),[41,42]$ with temperature controlled (electronic thermostat) between 363 and $463 \mathrm{~K} \pm 2 \mathrm{~K}$. The central neck was closed with a Teflon plug carrying the working electrode (a 99.999\% Au plate $0.6 \mathrm{~cm}^{2}$ ), left neck with a Teflon plug holding an argon glass inlet-outlet and glass Luggin capillary with magnesium reference electrode ( $3 \mathrm{~mm}$ diameter $99.999 \% \mathrm{Mg}$ wire) whose tip was placed close to the working electrode. Finally, the right neck was closed with a Teflon plug holding magnesium anode $(99.999 \% \mathrm{Mg})$ in the shape of a curved rectangular shovel $\left(7.5 \mathrm{~cm}^{2}\right.$ active surface area) and a tube of thin glass with a thermocouple. In order to create a moisture-free atmosphere around the cell, the whole cell setup was placed into a transparent plastic "glove box". Special attention was paid to the chemicals for the melt preparation. The melts used in experiments were: eutectic mixture $\left[\mathrm{Mg}\left(\mathrm{NO}_{3}\right)_{2} \cdot 6 \mathrm{H}_{2} \mathrm{O}+\mathrm{NH}_{4} \mathrm{NO}_{3} \cdot \mathrm{XH} \mathrm{H}_{2} \mathrm{O}\right]$ and nonaqueous $\left[\mathrm{Mg}\left(\mathrm{NO}_{3}\right)_{2}+\mathrm{NH}_{4} \mathrm{NO}_{3}\right]$ eutectic mixture. Precise quantity of the mixture $\mathrm{Mg}\left(\mathrm{NO}_{3}\right)_{2} \cdot 6 \mathrm{H}_{2} \mathrm{O}$ and $\mathrm{NH}_{4} \mathrm{NO}_{3} \cdot \mathrm{XH}_{2} \mathrm{O}$ was placed into the cell supplied with the electrodes. Then, the closed cell was placed into the heating mantel, argon supply was turned on and the system was heated gradually to the wanted temperature. However, it was soon established, using SEM, EDS and XRD analysis, that Mg UPD onto gold from this melt showed the deposit with less $\mathrm{Mg}$ than expected and no clear evidence of $\mathrm{Mg} / \mathrm{Au}$ alloys. Therefore, 
further Mg UPD processes have taken place in the melt made of nonaqueous magnesium/ammonium nitrate eutectic mixture $\left[\mathrm{Mg}\left(\mathrm{NO}_{3}\right)_{2}+\mathrm{NH}_{4} \mathrm{NO}_{3}\right]$.

To this end, we have succeeded in water removal from magnesium nitrate hexahydrate and the preparation process for melt made of nonaqueous magnesium/ammonium nitrate eutectic mixture $\left[\mathrm{Mg}\left(\mathrm{NO}_{3}\right)_{2}+\mathrm{NH}_{4} \mathrm{NO}_{3}\right]$ has been described in details elsewhere [41-43].

Prior to the electrochemical measurements, all used electrodes were mechanically polished by emery paper (FEPA P-4000) to a mirror finish and then etched. Gold cathode $(99.999 \% \mathrm{Au}$ ) was etched in aqua regia $\left(1: 3\right.$ volume ratio $\left.\mathrm{HNO}_{3}+\mathrm{HCl}\right)$, for several ten-second intervals separated by rinsing with deionized water. Magnesium anode and reference electrodes $(99.999 \% \mathrm{Mg})$ were etched for about $20-50 \mathrm{~s}$ in the solution made of conc. $\mathrm{HNO}_{3}+$ conc. $\mathrm{H}_{2} \mathrm{SO}_{4}+$ deionized water $\left(78.2 \mathrm{~cm}^{3}+23.4 \mathrm{~cm}^{3}+\right.$ $989.4 \mathrm{~cm}^{3}$, respectively). After treatment, all electrodes were rinsed with deionized water, absolute ethyl alcohol, dried and mounted into the cell.

Two electrochemical techniques used in the experiments were: linear sweep voltammetry (LSV) and potential step. All the reported potentials of working electrodes in this work were measured relative to the equilibrium potential of magnesium reference electrode in the melt used under given conditions [41-43].

LSV experiments included the potential scanned from a starting potential, $E_{S}$ (usually 50 to $100 \mathrm{mV}$ more negative than the reversible potential of Au working electrode) to a final potential, $E_{\mathrm{F}}(0.050-0.100 \mathrm{~V}$ positive to the reversible potential of $\mathrm{Mg}$ ), followed by the return scan. The sweep rates used were between $5 \mathrm{mVs}^{-1}$ and $100 \mathrm{mVs}^{-1}$. System responses were recorded by Potentiostat/Galvanostat Model 273 A (Princeton Applied Research, Oak Ridge, TN, USA) and accompaning software (Princeton Applied Research, Oak Ridge, TN, USA).

The procedure for the potential step method included change of the working electrode potential from an initial potential, $E_{\mathrm{I}}$ (50 to $100 \mathrm{mV}$ more negative to gold equilibrium potential in the given melt) to a potential, $E_{X}$ (50 to $100 \mathrm{mV}$ more positive to magnesium equilibrium potential in the given melt). EX potential was held constant for 120 and $600 \mathrm{~min}$, whereupon the working electrode was retrieved from the cell under potential in order to preserve deposited material or possible alloys formed during UPD of magnesium.

The deposit on the gold electrode was washed in the glove box with absolute ethyl alcohol to remove the melt residue. Then, the sample was transferred out of the box and kept without exposure to the atmosphere. Scanning electron microscope (SEM) with an energy dispersive spectroscopy (EDS) (SEM- “JEOL", model JSM-5800, Tokyo, Japan, EDS—“'Oxford INCA 3.2", Abingdon, UK.) and energy dispersive X-ray spectroscopy (EDX-maping-Oxford IncaEnergy EDX, Abingdon, UK) were used to examine the surface and the element analysis of the electrodeposits. The crystal structures of alloys were characterized by XRD (XRD—“"Enraf Nonius powder diffractometer", Delft, The Netherlands).

\section{Results and Discussion}

Potentiodynamic polarization curves and cyclic voltammetry measurements performed on gold working electrode with magnesium reference and counter electrodes have shown that magnesium reversible potential in the used magnesium nitrate melts was stable. The reversible potential of polycrystalline gold in the magnesium/ammonium nitrate eutectic mixture melt was $1.532 \pm 0.025 \mathrm{~V}$ at temperatures $370-440 \mathrm{~K}$ and in the nonaqueous magnesium/ammonium nitrate eutectic mixture melt was $1.340 \mathrm{~V} \pm 0.030 \mathrm{~V}$ at temperatures between 400 and $500 \mathrm{~K}$.

Examples of linear sweep voltammograms conducted on gold electrodes using different starting and final potentials and temperatures are given in Figure 1a,b. Common characteristics of the voltammograms studied in magnesium nitrate melts system indicated presence of several reduction peaks without oxidation counterparts, Figure 1a,b. Even when the cathodic end potential, $E_{\mathrm{F}}$, was pushed into the magnesium overpotential range, stripping peaks were not observed. In some cases, reduction peaks were spread over a wider range of applied potentials without obvious steeper increase or decrease of current density. Similar voltammograms peaks could be obtained for the 
processes that start successively one after the other at potentials whose values are close and proceed further simultaneously (often the next process starts with an increasing rate at the same time that a previous process ends with a constant or diminishing rate). It should be reiterated that the obtained current peak values at each potential recorded represent the sum of rates of all the processes taking part at that particular potential.
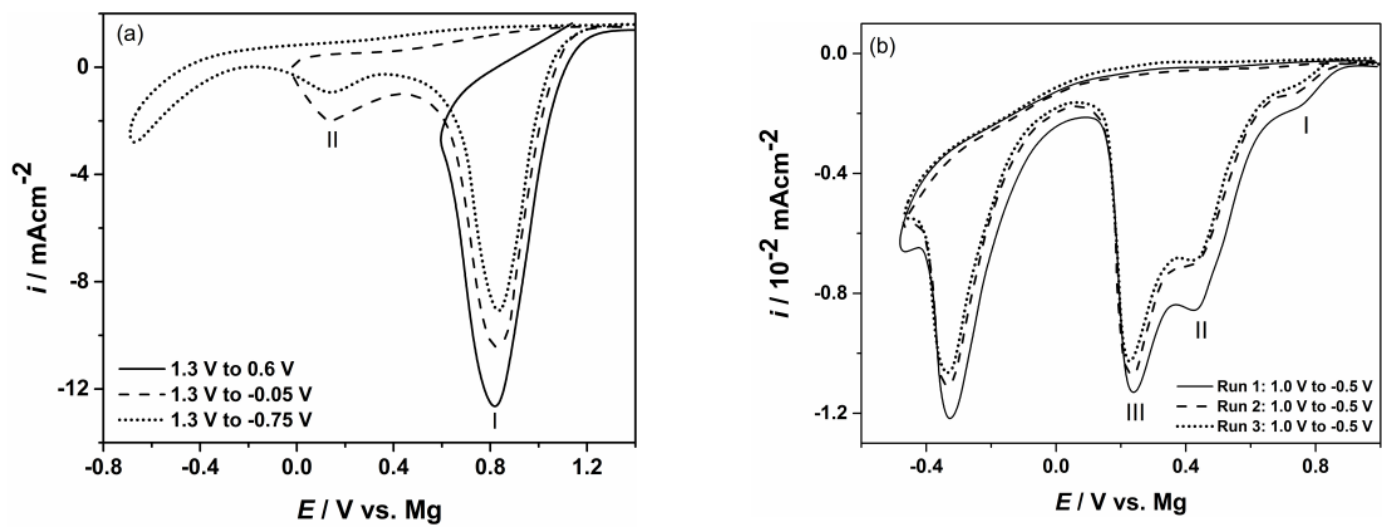

Figure 1. Typical cyclic voltammograms recorded on Au electrode obtained with scan rate $10 \mathrm{mV} / \mathrm{s}$ in: (a) magnesium/ammonium nitrate eutectic mixture melt at $400 \mathrm{~K}$; (b) nonaqueous magnesium/ammonium nitrate eutectic mixture melt at $460 \mathrm{~K}$.

Peak I in the voltammograms of Figure 1a reflects nitrate reduction processes which start around $0.900 \mathrm{~V}$ when water is present in the melt [41]. From voltammograms recorded in nonaqueous eutectic mixture melt this current wave is almost absent, Figure 1b. A broader cathodic peak II, appearing in the voltammograms obtained from both nitrate melts, presents the next group of reactions which have very close and more negative nitrate reduction potentials [33,34,41]. Experiments conducted in nitrate melts when water was present, Figure $1 \mathrm{a}$, showed that nitrate anion reduction processes take place successively in a potential range from rather positive values to those close to $0.000 \mathrm{~V}$, where cathodic peak current density decreases close to zero. At slightly more negative potentials to the previous (but still in Mg UPD region) another reduction current wave appears in nonaqueous eutectic mixture (peak III Figure 1b) and most probably belongs to the next group of the nitrate reduction processes $[33,34,41]$.

The processes that could produce reduction peaks in the magnesium underpotential region investigated and melts used, apart from ones brought about by the magnesium underpotential deposition itself, can be found in research reports published some time ago [33,34]. Therein, the potentials of the reactions are related to $\mathrm{Na}, \mathrm{K}$ or Li reference electrodes and cannot be directly used for comparison with our results. However, it can be assumed with enough certainty that the sequence of reaction potentials and the differences between the potentials of therein proposed processes are preserved in our systems also, but with respect to the magnesium reference potential. Of course, absolute values of the reaction potentials discussed must be different by the amounts reflecting differences in reference potentials of $\mathrm{Na}, \mathrm{K}$ and $\mathrm{Li}$ in their nitrate melts $[33,34]$ and magnesium reference potential in used nitrate melts.

As described above, the change of the gold electrode potential from positive values to the magnesium reversible potential value (magnesium UPD region), induces a number of reactions which include formation of different nitrogen species, very reactive oxygen anion $\mathrm{O}^{2-}, \mathrm{OH}^{-}$and sometimes water. All produced gases were removed from the electrochemical cell by the argon stream, and oxidation reaction back to initial $\mathrm{NO}_{3}{ }^{-}$or $\mathrm{H}_{2} \mathrm{O}$ could no longer be expected when the gold electrode potential is reversed into positive direction. Furthermore, $\mathrm{O}^{2-}$ produced in inner and outer parts of the electrochemical double layer very quickly engaged in reactions with $\mathrm{Mg}^{2+}$ present $[25,33,34,43,44]$ with the result being formation of insoluble magnesium oxides in 
the magnesium UPD region. Additionally, the increase of reduction current densities observed in the voltammograms in the magnesium nitrate melts with $\mathrm{NH}_{4} \mathrm{NO}_{3}$, at constant temperature in the magnesium UP region investigated, suggests reduction of ammonium ions [33,34]. Under given conditions, this reaction is also irreversible. As a result, when the electrode potential was reversed into the positive direction, no anodic voltammogram peaks could be recorded. Observed absence of anodic counterparts to cathodic peaks was a subject of discussion in a number of works $[25,33,34,43,44]$. The studies emphasize that changes of the gold electrode potential from anodic to cathodic values (compared to the magnesium reversible potential) in nitrate melts make the working electrode surface become partially, or fully, covered with MgO layers. These layers do not dissolve when the potential is returned to the starting positive value and eventually passivate the electrode. Therefore, it can be concluded that anodic voltammogram peaks cannot be expected in the magnesium UP region examined.

The absence of characteristic cathodic current peak in the voltammograms on gold electrode around $0.100 \mathrm{~V}$ depicting magnesium UPD from nitrate melts used, does not conclude that there was no magnesium electrodeposited [25-27,41-43]. It is logical to assume that the reduction peaks obtained by LSV measurements on the gold working electrode from nonaqueous magnesium/ammonium nitrate melt used in the magnesium underpotential region are sums of partial current densities for: $\mathrm{Mg}^{2+}$ underpotential reduction, nitrate anion reductions and ammonium cation reduction. Being a sum, the recorded current waves suggest small magnesium underpotential deposition partial current densities. Such small current densities exhibited by the UPD voltammograms from similar melts $[41,45,46]$ were characteristic of deposited metal monolayers diffusing into the substrate and forming alloys.

SEM photographs, EDS and EDX results showed evidence of magnesium and magnesium oxide on the surface of the gold electrode from both kinds of melts. Figures $2-4$ and Table 1 display SEM, EDS and EDX results obtained from the gold electrode held on electrode potential of $0.100 \mathrm{~V}$ in the melts made of nonaqueous eutectic $\left[\mathrm{Mg}\left(\mathrm{NO}_{3}\right)+\mathrm{NH}_{4} \mathrm{NO}_{3}\right]$ mixture and of eutectic $\left[\mathrm{Mg}\left(\mathrm{NO}_{3}\right) \cdot 6 \mathrm{H}_{2} \mathrm{O}+\right.$ $\left.\mathrm{NH}_{4} \mathrm{NO}_{3} \cdot \mathrm{XH}_{2} \mathrm{O}\right]$ mixture at $T=400 \mathrm{~K}$ and $460 \mathrm{~K}$. SEM photographs obtained showed cube shaped agglomerates almost uniformly distributed over entire electrode surface (Figure 2a) in the first case, and significant roughens and coarse morphology with a few nodules in the second case, Figure $2 b$.
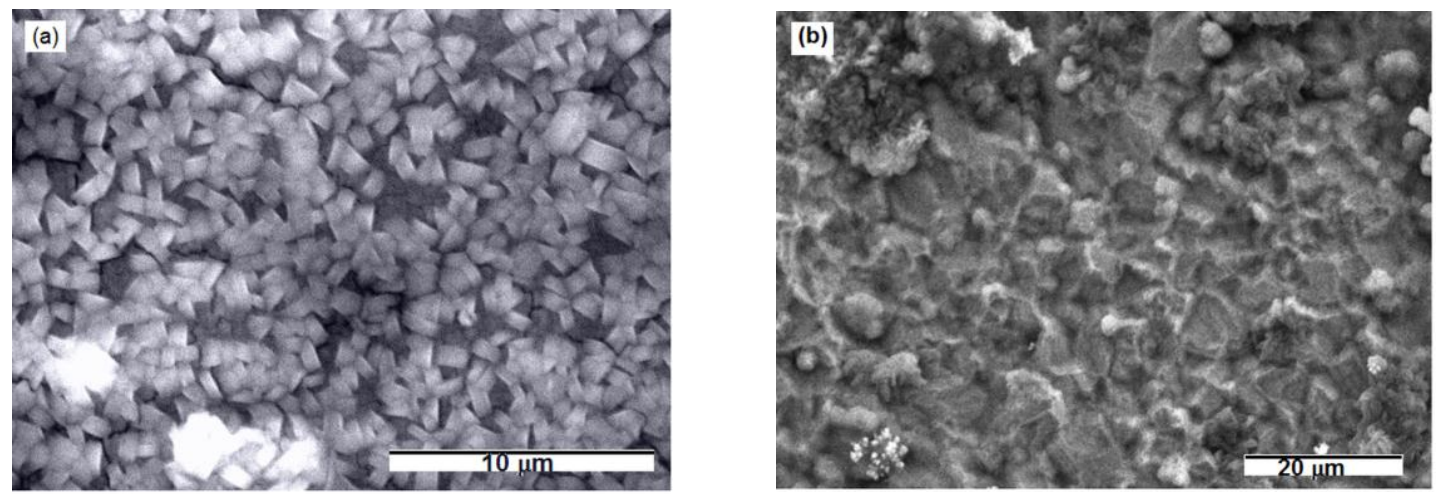

Figure 2. Scanning electron microscopy (SEM) micrographs of Au substrate after Mg electrodeposition by using potentiostatic techniques from: (a) magnesium/ammonium nitrate eutectic mixture melt at $400 \mathrm{~K}$ and $(\mathbf{b})$ nonaqueous magnesium/ammonium nitrate eutectic mixture melt at $460 \mathrm{~K}$. 

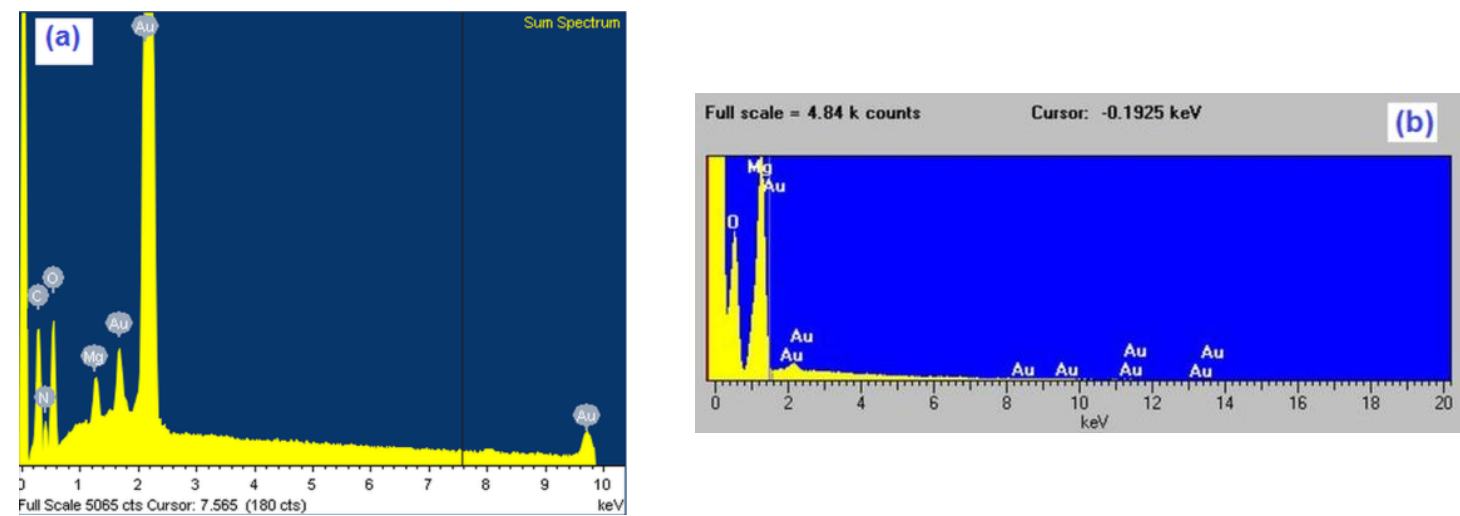

Figure 3. Characteristic EDS (energy dispersive spectrometry) spectra of gold samples after two hours time of magnesium underpotential depositionfrom: (a) magnesium/ammonium nitrate eutectic mixture melt at $400 \mathrm{~K}$ and (b) nonaqueous magnesium/ammonium nitrate eutectic mixture melt at $460 \mathrm{~K}$.

(a)

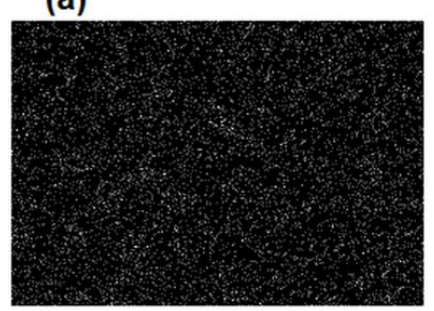

Mg Ka_1

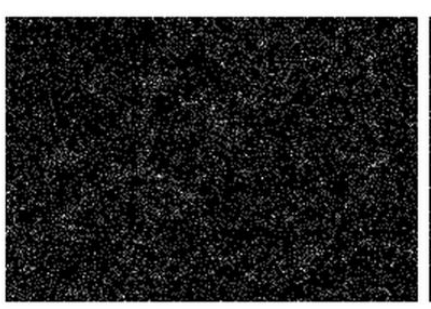

O Ka1

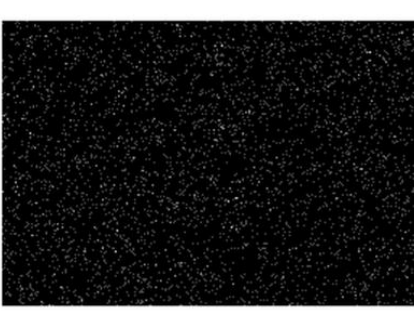

N Ka 12

(b)

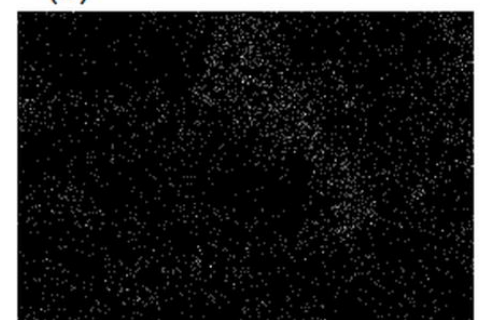

Mg Ka1_2

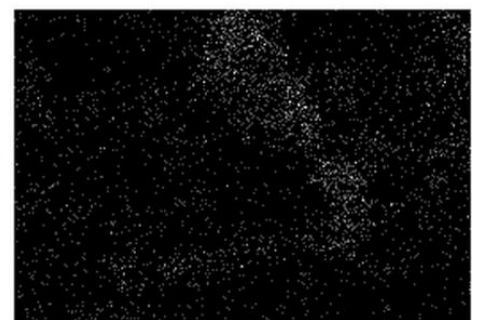

O Ka1

Figure 4. EDX maps of magnesium, oxigen and nitrogen distribution after $2 \mathrm{~h}$ of magnesium underpotential deposition onto gold substrate from: (a) magnesium/ammonium nitrate eutectic mixture melt at $400 \mathrm{~K}$ and (b) nonaqueous magnesium/ammonium nitrate eutectic mixture melt at $460 \mathrm{~K}$

Table 1. Results of EDS semi-quantitative analysis for the Au substrates exposed to constant potential of $+0.100 \mathrm{~V}$ for $2 \mathrm{~h}$ at $400 \mathrm{~K}$ and $460 \mathrm{~K}$ in used melts.

\begin{tabular}{ccccc}
\hline \multirow{2}{*}{ Element } & \multicolumn{2}{c}{$\begin{array}{c}\text { Magnesium/Ammonium Nitrate } \\
\text { Eutectic Mixture at 400 K }\end{array}$} & $\begin{array}{c}\text { Nonaqueous Magnesium/Ammonium } \\
\text { Eutectic Mixture at 460 K }\end{array}$ \\
\hline & Element (\%) & Atomic (\%) & Element $(\%)$ & Atomic (\%) \\
$\mathrm{O} \mathrm{K}$ & 71.52 & 85.26 & 65.06 & 75.52 \\
$\mathrm{Mg} \mathrm{K}$ & 17.42 & 13.67 & 24.96 & 23.5 \\
$\mathrm{Au} \mathrm{M}$ & 11.06 & 1.07 & 9.98 & 0.98 \\
Total & 100.0 & 100.0 & 100.0 & 100.0 \\
\hline
\end{tabular}

Typical examples of XRD analysis results of the gold sample exposed to the underpotential of $0.100 \mathrm{~V}$ in the melts mentioned above are presented in Figure 5a, $T=400 \mathrm{~K}, \mathrm{~b}$ and $\mathrm{c}, \mathrm{T}=460 \mathrm{~K}$. 
It was revealed that there were $\mathrm{Mg} / \mathrm{Au}$ alloys formed only during magnesium UPD onto working substrate from the nonaqueous melts. The XRD analysis (Figure 5a) revealed no clear evidence of $\mathrm{Mg}$ underpotential deposition and $\mathrm{Mg} / \mathrm{Au}$ alloys formation from magnesium/ammonium nitrate eutectic mixture melt with water present.

EDS analysis of the same samples showed the presence of magnesium in the surfaces of electrodes exposed to magnesium UPD from both kinds of melts used, although the presence of oxides was by far higher in the case of melt with water present. Presence of oxygen in EDS results was impossible to avoid because the samples had to be exposed to the air during handling. The white areas in the EDX scan from Figure 4. indicate positions and distribution of the elements $(\mathrm{Mg}, \mathrm{O}, \mathrm{N})$ present in the sample surfaces.
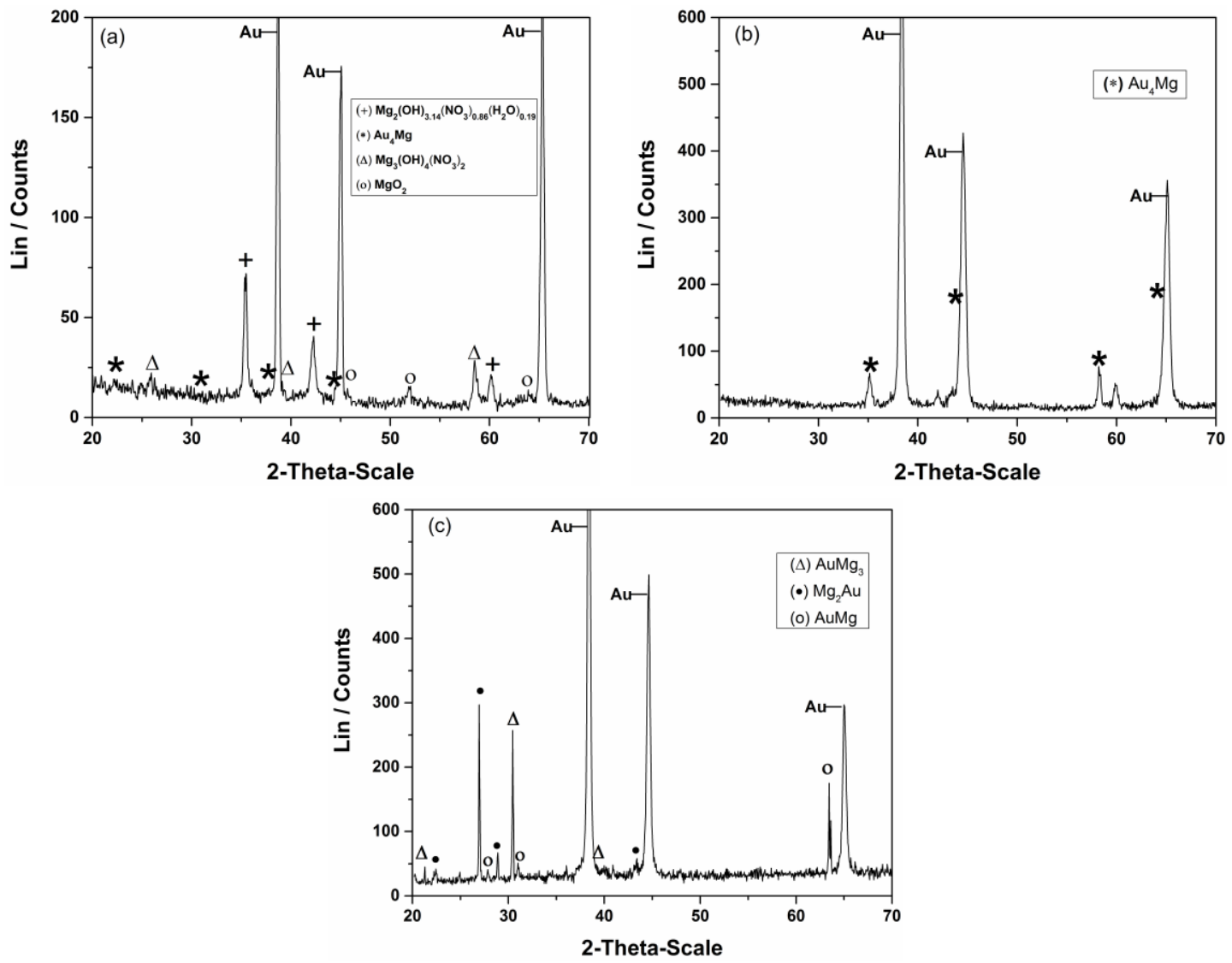

Figure 5. Diffraction patterns of gold samples after magnesium underpotential deposition at $E_{\mathrm{X}}=+0.100 \mathrm{~V}$ in: (a) magnesium/ammonium nitrate eutectic mixture at $400 \mathrm{~K}$ for $2 \mathrm{~h}$; (b) [47] and (c) nonaqueous magnesium/ammonium eutectic mixture melt at $460 \mathrm{~K}$ for $2 \mathrm{~h}$ and $5 \mathrm{~h}$, respectively.

A tentative explanation can be that the reduction of water, when present, produces hydroxides and active oxygen which with $\mathrm{Mg}(\mathrm{II})$ ions present in the electrode double layer feed formation of porous structures of the deposited oxides, Figure 6. In addition reduced oxygen species probably diffuse through pores into the deposit formed and with $\mathrm{Mg}^{2+}$ or nitrate ions create different compounds which crystalized on the electrode surface. The presence of the agglomerations on electrode surface can probably be blamed for the decrease in the concentration of free $\mathrm{Mg}^{2+}$ ions on the gold surface which could participate in $\mathrm{Mg} / \mathrm{Au}$ alloy formation. It is assumed that in magnesium/ammonium nitrate eutectic mixture due to moisture magnesium hydroxide is formed which could be transformed into oxides during oxidation processes at temperatures above $570 \mathrm{~K}$. The process depending on the value of the thermal decomposition constant, but in nitrate melts at given temperature $(400 \mathrm{~K})$ it seems that partial decomposition of $\mathrm{Mg}(\mathrm{OH})_{2}$ is taking place and is followed by $\mathrm{NH}_{4} \mathrm{NO}_{3}$ dissociation, 
which appears in $\mathrm{Mg}_{3}(\mathrm{OH})_{4}\left(\mathrm{NO}_{3}\right)_{2}$ and $\mathrm{Mg}_{2}(\mathrm{OH})_{3.14}\left(\mathrm{NO}_{3}\right)_{0.86}\left(\mathrm{H}_{2} \mathrm{O}\right)_{0.19}$ formation (Figures 4a and 5a). It looks like that compounds are solid at given temperature $(400 \mathrm{~K})$ and its precipitation on the electrode surface could cause pseudo-passivation. The formation of the passivating layer on the electrode surface may work as a barrier preventing $\mathrm{Mg}$ adatoms from diffusing into the bulk of the gold substrate.

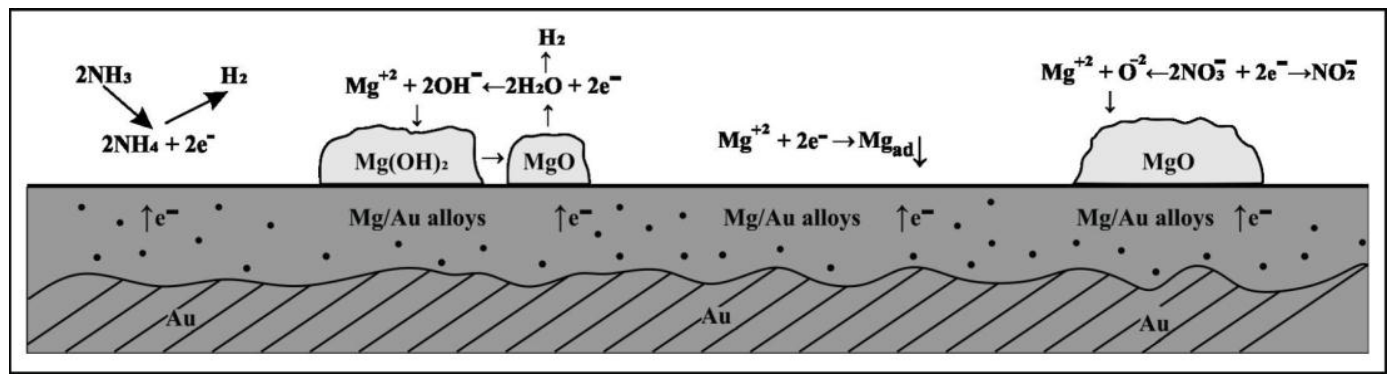

Figure 6. Schematic representation of the processes taking place on the surface of Au cathode during magnesium underpotential deposition and $\mathrm{Mg} / \mathrm{Au}$ alloys formation in the melts made of nonaqueous eutectic $\left[\mathrm{Mg}\left(\mathrm{NO}_{3}\right)+\mathrm{NH}_{4} \mathrm{NO}_{3}\right]$ mixture and of eutectic $\left[\mathrm{Mg}\left(\mathrm{NO}_{3}\right) \cdot 6 \mathrm{H}_{2} \mathrm{O}+\mathrm{NH}_{4} \mathrm{NO}_{3} \cdot \mathrm{XH}_{2} \mathrm{O}\right]$ mixture.

The XRD-obtained spectra (Figure $5 \mathrm{~b}, \mathrm{c}$ ) indicate $\mathrm{Mg} / \mathrm{Au}$ alloy formation by magnesium underpotential deposition from the nonaqueous melt used. The alloys identified are listed in Table 2.

Table 2. The alloys identified on gold samples after magnesium deposition at $460 \mathrm{~K}$ and different deposition times in nonaqueous magnesium/ammonium eutectic mixture.

\begin{tabular}{cccccc}
\hline Tem. (K) & $\begin{array}{c}\text { Time, } \\
\boldsymbol{\tau} / \mathbf{h}\end{array}$ & $\begin{array}{c}\text { Identified } \\
\text { Phase }\end{array}$ & Structure & $\begin{array}{c}\text { Approximate } \\
\text { Composition wt. \% Au }\end{array}$ & References \\
\hline \multirow{3}{*}{$460 \mathrm{~K}$} & 2 & $\mathrm{Au}_{4} \mathrm{Mg}$ & Orthorhombic & $94-97$ & {$[48]$} \\
\cline { 2 - 6 } & 5 & $\mathrm{AuMg}$ & Cubic & $85-95$ & {$[49]$} \\
& $\mathrm{AuMg}_{3}$ & Hexagonal & $73-80$ & {$[50]$} \\
$\mathrm{Mg}_{2} \mathrm{Au}$ & Orthorhombic & $73-80$ & {$[51]$} \\
\hline
\end{tabular}

$\mathrm{Mg}$ and Au atomic radii do not differ substantially [52,53] and according to the Hume/Rothery "15\% rule" [54], Mg and Au fulfill the required conditions to form alloys (solid solutions). It was also reported that the formation of stable alloy layer was correlated with the atomic/ionic radii of two metals and that combination of $\mathrm{Mg}$ and $\mathrm{Au}$ atoms, which have similar radii, led to stable alloy phase [55]. A stable $\mathrm{Au} / \mathrm{Mg}$ alloy possesses a low work function similar to the reactive $\mathrm{Mg}$ [4], because the doping $\mathrm{Mg}$ atom hardly deforms the electronic structure of $\mathrm{Au} / \mathrm{Mg}$ clusters [3,11,56].

The phase diagram of the $\mathrm{Au}-\mathrm{Mg}$ system is very complex, with a number of phases [57]. According to the diagram [58] the maximum solid solubility of $\mathrm{Au}$ in $\mathrm{Mg}$ is $\sim 0.1$ at. \% $\mathrm{Au}$, and the solid solubility of $\mathrm{Mg}$ in $\mathrm{Au}$ has not yet been determined. Thermal analyses showed a wide range of solid solubility of $\mathrm{Mg}$ in $\mathrm{Au}$, and at temperatures above $1080 \mathrm{~K}$ in the composition range of 94 to $97 \mathrm{mass} \% \mathrm{Au}$, several phases of different structures have been found in the system: surface centered $\mathrm{Au}_{4} \mathrm{Mg}$, base-centered orthorhombic $\mathrm{Au}_{3} \mathrm{Mg}$, and even hexagonal $\mathrm{Au}_{41} \mathrm{Mg}_{13}$. According to the same diagram at slightly lower temperatures (above $1053 \mathrm{~K}$ ) in the composition range of 80 to $85 \mathrm{mass} \% \mathrm{Au}$, stoichiometric intermetallic compound $\mathrm{Mg}_{2} \mathrm{Au}$ is being formed and at even lower temperatures above $1000 \mathrm{~K}$, within 73-80 mass\% Au hexagonal $\mathrm{Mg}_{3} \mathrm{Au}$ is registred. It was also shown that the ordered nonstoichiometric intermediate $\mathrm{MgAu}$ phase has a wide homogeneity range including several new phases in the composition range of 70 to 80 at. \% $\mathrm{Au}$ around the $\mathrm{MgAu}_{3}$ composition [59] like the stoichiometric $\mathrm{Mg}_{5} \mathrm{Au}$, or $\mathrm{Mg}_{22} \mathrm{Au}_{78}, \mathrm{Mg}_{24} \mathrm{Au}_{76}$ and $\mathrm{Mg}_{26} \mathrm{Au}_{74}$ [59].

Some of the alloys described by the literature cited above $[57,58]$ have been formed in studied magnesium underpotential deposition onto gold in used, nonaqueous magnesium/ammonium 
eutectic mixture, but at temperatures which are several hundred degrees Kelvin lower (see Table 2). The main phase formed by the $\mathrm{Mg}$ UPD onto gold electrode at $420 \mathrm{~K}$ was $\mathrm{Au}_{4} \mathrm{Mg}$. The alloys formed by magnesium underpotential deposition at $460 \mathrm{~K}$ were $\mathrm{AuMg}_{3}, \mathrm{Mg}_{2} \mathrm{Au}$ and $\mathrm{AuMg}$. As would be expected, increase in the deposition temperature increased solid state interdiffusion rates. Prolonged $\mathrm{UPD}$ at constant temperature resulted in $\mathrm{Mg}$ content increase in $\mathrm{Au} / \mathrm{Mg}$ alloys which is recorded by the increased number of alloy phases observed.

Which fraction of magnesium adatoms formed by underpotential deposition on gold surface participated in magnesium oxide formation and which diffused into the substrate and contributed to magnesium/gold alloys formation could not be concluded by linear sweep voltammetry, EDS or XRD results. LSV results indicated and EDS and XRD results confirmed both the magnesium oxide and magnesium/gold alloys formation at the surface of the gold electrode in nonaqueous magnesium/ammonium eutectic mixture used as a result of magnesium underpotential deposition. The process of magnesium oxide formation from nitrate melts has been described elsewhere [60-62]. In addition, some novel results $[26,43,44]$ suggest that every amount of reactive magnesium on the electrode surface in the presence of $\mathrm{O}^{2-}$ and $\mathrm{OH}^{-}$anions very quickly becomes $\mathrm{MgO}$. Therefore, the surface of the gold working electrode becomes partially covered with $\mathrm{MgO}$ even in the first linear change of the potential from anodic end to cathodic end of the magnesium underpotential range. This, however, did not preclude some quantity of magnesium adatoms from participating in magnesium-gold alloy formation by interdiffusion. A portion of magnesium ions in $\mathrm{MgO}$ probably diffuses through the oxide layer to the gold surface where they become discharged into magnesium adatoms which are then participating in the interdiffusion processes of alloy formation. Fast and unavoidable formation of insoluble $\mathrm{MgO}$ in the magnesium underpotential deposition range on gold from used nitrate melts explains the quasi-passivation of the working electrode and the lack of anodic current peaks on the voltammograms recorded.

\section{Conclusions}

Magnesium was successfully electrodeposited onto a gold electrode from a nonaqueous magnesium/ammonium eutectic mixture, at potentials positive to $0.100 \mathrm{~V}$ and temperatures between 400 and $500 \mathrm{~K}$. However, even a small quantity of water inhibited the $\mathrm{Mg}$ electrodeposition from magnesium/ammonium eutectic mixture.

This is the first observation of $\mathrm{Au} / \mathrm{Mg}$ alloys- $\mathrm{AuMg}_{3}, \mathrm{Mg}_{2} \mathrm{Au}, \mathrm{Au}_{4} \mathrm{Mg}$ and $\mathrm{AuMg}$ - being formed as a result of magnesium underpotential deposition onto gold substrate from magnesium nitrate melts used.

Alloys obtained were formed at temperatures several hundred degrees Kelvin lower than the temperatures which are needed for their formation by thermal means.

It appears that underpotential deposition of metals that are unsuitable for electrodeposition from aqueous electrolytes, like magnesium, can be performed from nitrate melts at low temperatures and that this can lead to the formation of alloys in a very controlled manner under technologically suitable conditions.

Acknowledgments: This work was supported by the Ministry of Education, Science and Technology of the Republic of Serbia (Grant OI 172060 and Grant OI 172046).

Author Contributions: Vesna Cvetković and Nataša Vukićević performed most of the experiments and participated in manuscript writing, Niko Jovicevic provided SEM and EDS analysis and participated in manuscript writing, Jasmina Stevanović and Miomir Pavlović provided XRD analysis and helped with the corrections of the manuscript, Zoran Stevanović contributed materials and participated in manuscript writing, and Jovan Jovićević conceived the experiments and lead the manuscript writing.

Conflicts of Interest: The authors declare no conflict of interest. 


\section{References}

1. Takeda, Y.; Kuriiwa, T.; Kamegawa, A.; Okada, M. Grain size refinements of Au-Mg alloy by hydrogen absorption/desorption treatments. Mater. Trans. 2009, 50, 494-498. [CrossRef]

2. Oyamada, T.; Sasabe, H.; Adachi, C. Formation of MgAu alloy cathode by photolithography and its application to organic light-emitting diodes and organic field effect transistors. Electr. Eng. Jpn. 2005, 152, 37-42. [CrossRef]

3. Li, Y.F.; Kuang, X.Y.; Wang, S.J.; Li, Y.; Zhao, Y.R. Geometries, stabilities, and electronic properties of gold-magnesium $\left(\mathrm{Au}_{\mathrm{n}} \mathrm{Mg}\right)$ bimetallic clusters. Phys. Lett. Sect. A Gen. At. Solid State Phys. 2011, 375, 1877-1882.

4. Dubecký, M.; Dubecký, F. The work functions of $\mathrm{Au} / \mathrm{Mg}$ decorated $\mathrm{Au}(100), \mathrm{Mg}(001)$, and $\mathrm{AuMg}$ alloy surfaces: A theoretical study. J. Chem. Phys. 2014, 141, 94705. [CrossRef] [PubMed]

5. Burch, R. Gold catalysts for pure hydrogen production in the water-gas shift reaction: Activity, structure and reaction mechanism. Phys. Chem. Chem. Phys. 2006, 8, 5483-5500. [CrossRef] [PubMed]

6. Taylor, R.H.; Curtarolo, S.; Hart, G.L.W. Guiding the experimental discovery of magnesium alloys. Phys. Rev. B 2011, 84, 84101. [CrossRef]

7. Takenaka, T.; Ono, T.; Narazaki, Y.; Naka, Y.; Kawakami, M. Improvement of corrosion resistance of magnesium metal by rare earth elements. Electrochim. Acta 2007, 53, 117-121. [CrossRef]

8. Viestfrid, Y.; Levi, M.D.; Gofer, Y.; Aurbach, D. Microelectrode studies of reversible Mg deposition in THF solutions containing complexes of alkylaluminum chlorides and dialkylmagnesium. J. Electroanal. Chem. 2005, 576, 183-195. [CrossRef]

9. Bhattacharjee, D.; Mishra, B.K.; Deka, R.C. A DFT study on structure, stabilities and electronic properties of double Magnesium doped Gold clusters. RSC Adv. 2014, 4, 56571-56581. [CrossRef]

10. Majumder, C.; Anil K., K.; Puru, J. Structure and bonding of $\mathrm{Au}_{5} \mathrm{M}(\mathrm{M}=\mathrm{Na}, \mathrm{Mg}, \mathrm{Al}, \mathrm{Si}, \mathrm{P}$, and S) clusters. Phys. Rev. B 2006, 74, 1-6. [CrossRef]

11. Koyasu, K.; Naono, Y.; Akutsu, M. Photoelectron spectroscopy of binary Au cluster anions with a doped metal atom: AunM- (n =2-7), M= Pd, Ni, Zn, Cu, and Mg. Chem. Phys. Lett. 2006, 422, 62-66. [CrossRef]

12. Qu, J.; Wang, Y.; Xie, L.; Zheng, J.; Liu, Y.; Li, X. Hydrogen absorption-desorption, optical transmission properties and annealing effect of $\mathrm{Mg}$ thin films prepared by magnetron sputtering. Int. J. Hydrog. Energy 2009, 34, 1910-1915. [CrossRef]

13. Zaluska, A.; Zaluski, L.; Strom-Olsen, J.O. Nanocrystalline magnesium for hydrogen storage. J. Alloy. Compd. 1999, 288, 217-225. [CrossRef]

14. Rud, A.D.; Lakhnik, A.M.; Ivanchenko, V.G.; Uvarov, V.N.; Shkola, A.A.; Dekhtyarenko, V.A.; Ivaschuk, L.I.; Kuskova, N.I. Hydrogen storage of the Mg-C composites. Int. J. Hydrog. Energy 2008, 33, 1310-1316. [CrossRef]

15. Gremaud, R.; Broedersz, C.P.; Borsa, D.M.; Borgschulte, A.; Mauron, P.; Schreuders, H.; Rector, J.H.; Dam, B.; Griessen, R. Hydrogenography: An optical combinatorial method to find new light-weight hydrogen-storage materials. Adv. Mater. 2007, 19, 2813-2817. [CrossRef]

16. Noh, Y.Y.; Kim, J.J.; Yase, K.; Nagamatsu, S. Organic field-effect transistors by a wet-transferring method. Appl. Phys. Lett. 2003, 83, 1243-1245. [CrossRef]

17. Chadwick, A.F.; Vardar, G.; DeWitt, S.; Sleightholme, A.E.S.; Monroe, C.W.; Siegel, D.J.; Thornton, K. Computational Model of Magnesium Deposition and Dissolution for Property Determination via Cyclic Voltammetry. J. Electrochem. Soc. 2016, 163, A1813-A1821. [CrossRef]

18. Yoo, H.D.; Shterenberg, I.; Gofer, Y.; Gershinsky, G.; Pour, N.; Aurbach, D. Mg rechargeable batteries: An on-going challenge. Energy Environ. Sci. 2013, 6, 2265-2279. [CrossRef]

19. DeWitt, S.; Hahn, N.; Zavadil, K.; Thornton, K. Computational Examination of Orientation-Dependent Morphological Evolution during the Electrodeposition and Electrodissolution of Magnesium. J. Electrochem. Soc. 2016, 163, A513-A521. [CrossRef]

20. Liebenow, C. Reversibility of electrochemical magnesium deposition from Grignard solutions. J. Appl. Electrochem. 1997, 27, 221-225. [CrossRef]

21. Mohtadi, R.; Matsui, M.; Arthur, T.S.; Hwang, S.J. Magnesium borohydride: From hydrogen storage to magnesium battery. Angew. Chem. Int. Ed. 2012, 51, 9780-9783. [CrossRef] [PubMed] 
22. Kumar, N.; Siegel, D.J. Interface-Induced Renormalization of Electrolyte Energy Levels in Magnesium Batteries. J. Phys. Chem. Lett. 2016, 7, 874-881. [CrossRef] [PubMed]

23. Stafford, G.R.; Hussey, C.L. Electrodeposition of transition metal-aluminium alloys from chloroaluminate molten salts. In Advances in Electrochemical Science and Engineering; Alkire, R.C., Kolb, D.M., Eds.; Wiley-VCH Verlag GmbH: New York, NY, USA, 2001; Volume 7, pp. 275-348.

24. Kolb, D.M. The initial stages of metal deposition as viewed by scanning tunneling microscopy. In Advances in Electrochemical Science and Engineering; Alkire, R.C., Kolb, D.M., Eds.; Wiley-VCH Verlag GmbH: New York, NY, USA, 2001; Volume 7, pp. 107-150.

25. Martínez, A.M.; Børresen, B.; Haarberg, G.M.; Castrillejo, Y.; Tunold, R. Electrodeposition of Magnesium from $\mathrm{CaCl}_{2}-\mathrm{NaCl}-\mathrm{KCl}-\mathrm{MgCl}_{2}$ Melts. J. Electrochem. Soc. 2004, 151, C508-C513. [CrossRef]

26. Martínez, A.M.; Børresen, B.; Haarberg, G.M.; Castrillejo, Y.; Tunold, R. Electrodeposition of Magnesium from the eutectic LiCl-KCl melt. J. Appl. Electrochem. 2004, 34, 1271-1278. [CrossRef]

27. Lu, Z.; Schechter, A.; Moshkovich, M.; Aurbach, D. On the electrochemical behavior of magnesium electrodes in polar aprotic electrolyte solutions. J. Electroanal. Chem. 1999, 466, 203-217. [CrossRef]

28. Wang, P.; NuLi, Y.; Yang, J.; Feng, Z. Mixed Ionic Liquids as Electrolyte for Reversible Deposition and Dissolution of Magnesium. Surf. Coat. Technol. 2006, 201, 3783-3787. [CrossRef]

29. Simka, W.; Puszczyk, D.; Nawrat, G. Electrodeposition of metals from non-aqueous solutions. Electrochim. Acta 2009, 54, 5307-5319. [CrossRef]

30. Abbott, A.P.; McKenzie, K.J. Application of ionic liquids to the electrodeposition of metals. Phys. Chem. Chem. Phys. 2006, 8, 4265-4279. [CrossRef] [PubMed]

31. Watkins, T.; Kumar, A.; Buttry, D.A. Designer Ionic Liquids for Reversible Electrochemical Deposition/Dissolution of Magnesium. J. Am. Chem. Soc. 2016, 138, 641-650. [CrossRef] [PubMed]

32. Bhatia, K.; Sharma, R.C.; Gaur, H.C. Conductivity of molten hydrated salts: $\mathrm{Mg}\left(\mathrm{NO}_{3}\right)_{2} \cdot 6 \mathrm{H}_{2} \mathrm{O}+\mathrm{NH}_{4} \mathrm{NO}_{3}$ system. Electrochim. Acta 1978, 23, 1367-1369. [CrossRef]

33. Tkalenko, D.A. Elektrokhimiya Nitratnykh Rasplavov; Naukova Dumka: Kiev, Ukraine, 1983. (In Russian)

34. Tkalenko, D.A. Makrokinetika Katodnykh Protsessov v Gidroksidnykh i Nitratnykh Rasplavakh; Naukova Dumka: Kiev, Ukraine, 1993. (In Russian)

35. Ramana, K.V.; Sharma, R.C.; Gaur, H.C. Conductivity and viscosity of molten mixtures of ferric nitrate nonahydrate with hydrates of calcium, cadmium, magnesium, and zinc nitrates. J. Chem. Eng. Data 1990, 35, 293-297. [CrossRef]

36. Ramana, K.V.; Sharma, R.C.; Gaur, H.C. Conductivity and viscosity of molten mixtures of aluminum nitrate decahydrate with hydrates of calcium, cadmium, magnesium, and zinc nitrates. J. Chem. Eng. Data 1990, 35, 418-420. [CrossRef]

37. Vidu, R.; Hirai, N.; Hara, S. Comparative kinetic study of Cd diffusion into $\mathrm{Au}(100)$ and $\mathrm{Ag}(100)$ during electrodeposition. Phys. Chem. Chem. Phys. 2001, 3, 3320-3324. [CrossRef]

38. Radovic, B.S.; Edwards, R.A.H.; Jovicevic, J.N. Aluminium underpotential deposition from $\mathrm{AlCl}_{3}+\mathrm{NaCl}$ melts on gold electrodes. J. Electroanal. Chem. 1997, 428, 113-121. [CrossRef]

39. Radović, B.S.; Cvetković, V.S.; Edwards, R.A.H.; Jovićević, J.N. Al-Cu alloy formation by aluminium underpotential deposition from $\mathrm{AlCl}_{3}+\mathrm{NaCl}$ melts on copper substrate. Kov. Mater. 2010, 48, 159-171.

40. Radovic, B.; Edwards, R.A.H.; Cvetković, V.S.; Jovicevic, J.N. Al-Ag alloy formation by aluminium underpotential deposition from $\mathrm{AlCl}_{3}+\mathrm{NaCl}$ melts on silver substrate. Met. Mater. 2010, 48, 55-71. [CrossRef]

41. Cvetković, V.S.; Bjelica, L.J.; Vukićević, N.M.; Jovićević, J.N. Alloy formation by Mg underpotential deposition on $\mathrm{Al}$ from nitrate melts. Chem. Ind. Chem. Eng. Q. 2015, 21, 527-536. [CrossRef]

42. Cvetković, V.S.; Jovićevic, J.N.; Bjelica, L.J. Magnesium underpotential deposition from nitrate melts and alloy formation with platinum substrate. Kov. Mater. 2016, 54, 321-330. [CrossRef]

43. Cvetković, V.S. Underpotential Deposition of Magnesium from Nitrate Melts (in Serbian); Zadužbina Andrejević: Beograd, Serbia, 2012.

44. Amir, N.; Vestfrid, Y.; Chusid, O.; Gofer, Y.; Aurbach, D. Progress in nonaqueous magnesium electrochemistry. J. Power Sources 2007, 174, 1234-1240. [CrossRef]

45. Radović, B.S.; Cvetković, V.S.; Edwards, R.A.H.; Jovićević, J.N. Al-Fe alloy formation by aluminium underpotential deposition from $\mathrm{AlCl}_{3}+\mathrm{NaCl}$ melts on iron substrate. Int. J. Mater. Res. 2011, 102, 59-68. [CrossRef] 
46. Jovićević, N.; Cvetković, V.S.; Kamberović, Ž. J.; Jovićević, J.N. Al-Cd Alloy Formation by Aluminum Underpotential Deposition from $\mathrm{AlCl}_{3}+\mathrm{NaCl}$ Melts on Cadmium Substrate. Metall. Mater. Trans. B 2013, 44, 106-114.

47. Cvetković, V.S.; Jovićević, N.; Jovićević, J.N. Mg-Au Surface Alloy Formation by Magnesium Underpotential Deposition on Au from Nitrate Melts. In Proceedings of the 62nd Annual Meeting of the International Society of Electrochemistry, International Society of Electrochemistry, Niigata, Japan, 11-16 Sepetmber 2011; p. poster s03-P-012.

48. Burkhardt, V.K.; Schubert, K.; Toth, R.S.; Sato, H. Die Struktur der Phase $\mathrm{Au}_{77} \mathrm{Mg}_{23}$. Acta Crystallogr. 1968, B24, 137-142. [CrossRef]

49. Brauer, G.; Haucke, W. Kristallstruktur der intermetallischen Phasen MgAu und MgHg. Z. Phys. Chem. B 1936, 33, 304-310.

50. Range, K.-J.; Hafner, P. Structure refinement of $\mathrm{AuMg}_{3}, \mathrm{IrMg}_{3}$ and $\mathrm{IrMg}_{2.8}$. J. Alloy. Compd. 1993, 191, L5-L7. [CrossRef]

51. Daams, J.L.C.; Van Vucht, J.H. Contribution on the system Mg-Au-Hg. Philips J. Res. 1984, 39, $275-292$.

52. Clementi, E.; Raimondi, D.L.; Reinhardt, W.P. Atomic Screening Constants from SCF Functions. II. Atoms with 37 to 86 Electrons. J. Chem. Phys. 1967, 47, 1300-1307. [CrossRef]

53. Smith, D.W. Inorganic Substances. A Prelude to the Study od Descriptive Inorganic Chemistry; Cambridge University Press: Cambridge, UK, 1990.

54. Hume-Rothery, W.; Smallman, R.E.; Haworth, C.W. The Structure of Metals and Alloys, 5th ed.; The Metals and Metallurgy trust of the Institute of metals and Institution of Metallurgists: London, UK, 1969.

55. Cottrell, A.H. Introduction to Modern Theory of Metals; Institute of Materials: London, UK, 1988.

56. Balducci, G.; Ciccioli, A.; Gigli, G. A mass spectrometric and density functional study of the intermetallic molecules AuBe, AuMg, and AuCa. J. Chem. Phys. 2004, 121, 7748-7755. [CrossRef] [PubMed]

57. Predel, B. Au-Mg (Gold-Magnesium). In $A c-A u-A u-Z r$; Springer: Berlin/Heidelberg, Germany, 1992; pp. 1-2.

58. Nayeb-Hashemi, A.A.; Clark, J.B. Phase Diagram of Binary Magnesium Alloys. In Binary Alloy Phase Diagrams; ASM International: Materials Park, OH, USA, 1986; p. 198.

59. Hansen, M.; Anderko, K. Constitution of Binary Alloys; McGraw-Hill: New York, NY, USA, 1958.

60. Massalski, T.B.; Okamoto, H.; Subramanian, P.R.; Kacprzak, L. Binary Alloy Phase Diagrams, 2nd ed.; ASM: Metals Park, OH, USA, 1990.

61. Hashaikeh, R.; Szpunar, J.A. Electrolytic processing of MgO coatings. J. Phys. Conf. Ser. 2009, 165, 12008. [CrossRef]

62. Rao, K.V.; Sunandana, C.S. Structure and microstructure of combustion synthesized MgO nanoparticles and nanocrystalline $\mathrm{MgO}$ thin films synthesized by solution growth route. J. Mater. Sci. 2008, 43, 146-154. [CrossRef]

(C) 2017 by the authors. Licensee MDPI, Basel, Switzerland. This article is an open access article distributed under the terms and conditions of the Creative Commons Attribution (CC BY) license (http:/ / creativecommons.org/licenses/by/4.0/). 